\title{
João Dória: frames em estratégias comunicativas do discurso político no Facebook
}

\author{
Beatriz FERREIRA-SILVA® \\ Universidade Estadual de Campinas (UNICAMP)
}

\section{○}

OPEN ACCESS

EDITADO POR

- Raquel Freitag (UFS)

AVALIADO POR

- Leilane Ramos da Silva (UFS)

- Halysson Oliveira Dantas (UFC)

DATAS

- Recebido: 18/03/2020

- Aceito: 12/05/2020

- Publicado: 18/07/2020

\section{COMO CITAR}

Ferreira-Silva, B. (2020)

João Dória: framesem

estratégias comunicativas do discurso político no Facebook. Revista da Abralin, v. 19, n. 1, p. 1$26,2020$.
RESUMO

O trabalho parte de uma perspectiva textual-interativa de base sociocognitiva e analisa frames evocados em vídeos publicados na página oficial do ex-prefeito paulistano e atual governador de São Paulo, João Dória, na plataforma Facebook. O corpus abrange publicações de abril e maio de 2017 e dos mesmos meses em 2018, focalizando 16 vídeos. Tal período marca, em 2017, o início do mandato de prefeito e, em 2018, o momento em que João Dória deixa o mandato, meses antes das eleições para governador. A ancoragem referencial dos frames identificados pode mostrar como práticas políticas, comunicativas e linguísticas se alinham em um conjunto de estratégias.

\section{ABSTRACT}

This study presents a textual-interactive approach and socio-cognitive perspective, in order to analyze frames in speeches from videos posted on João Dória's official Facebook profile. Dória is a former mayor of São Paulo, the largest city in Brazil, and the current governor of State of São Paulo. The corpus is formed by posts from April and May 2017 and 2018, from where 16 videos were analyzed. In that period, 2017 symbolizes the beginning of the mayor's term, while 2018 symbolizes the final phase of Dória's term and the period before his election as state governor as well. The referential anchoring of the frames shows how political, communicative and linguistic practices are aligned according with a set of strategies. 


\section{REVISTA DA ABRALIN}

PALAVRAS-CHAVE

Frames. Facebook. Linguística Textual. Neurolinguística. Discurso político.

\section{KEYWORDS}

Frames. Facebook. Text Linguistics. Neurolinguistics. Political Discourse.

\section{Introdução}

O presente trabalho analisa a ancoragem referencial de frames evocados em um conjunto de dados divulgados online. Seu interesse de fundo reside em estudar as relações entre processos linguísticos, cognitivos e sociais. Processos de ancoragem referencial têm sido um dos focos de interface entre a Linguística Textual e os estudos sobre cognição - como assinala Morato (2017). A nosso ver, articular categorias de análise de base textual-interativa a frames e conceptualizações corresponde a uma abordagem relevante para a investigação de práticas linguísticas complexas, como aquelas de elaboração e circulação de vídeos de discursos políticos, por exemplo.

As práticas políticas eleitorais ou de governança pública consistem em uma instância da vida em sociedade de caráter decisório, quando projetos e formulações ideológicas sobre a realidade e o futuro, após serem levados ao voto, tornam-se passíveis de serem implantados e de impactar milhões de pessoas em inúmeras maneiras. Por conseguinte, as práticas linguísticas constitutivas dos processos políticos - mais especificamente os discursos políticos divulgados em vídeos online - podem ser um lócus importante para o desafio dos estudos sociocognitivos do texto. Tais estudos, além de tornarem possível uma descrição das conceptualizações presentes nos discursos políticos, permitem observar de que modo frames podem ser evocados como forma de estabelecer um projeto-dedizer e de gerar impactos específicos nos interlocutores, nos seguidores de mídia sociais e nos eleitores que tomam como base tais mídias e conteúdos.

No Brasil, democracia concorrencial em que diferentes candidatos participam do processo eleitoral, torna-se ainda maior a importância de que sejam observados e analisados textos e discursos presentes nos processos políticos, sobretudo após a popularização de mídias sociais, como o Facebook, que trouxeram novos modos de circulação e maior alcance para os discursos políticos entre a população.

Os vídeos publicados na plataforma de mídia social Facebook por João Dória ${ }^{1}$ parecem ocupar um lugar de destaque no entrelaçamento recente entre práticas linguísticas, conceptualizações que as estruturam e novos contextos de circulação do discurso político. João Dória é atualmente

1 Disponível em: https://pt-br.facebook.com/jdoriajr/. Acesso em: 27 jun. 2019. 


\section{REVISTA DA ABRALIN}

governador do estado de São Paulo, foi prefeito da cidade de São Paulo eleito para o mandato entre 2017-2020, governador eleito para o mandato entre 2019-2022 e tornou-se conhecido nacionalmente por utilizar frequentemente a mídia social Facebook para divulgar vídeos dirigidos à população, seja durante seu mandato como prefeito, seja durante o período de ambas as campanhas eleitorais das quais participou.

A possibilidade de evocar frames e conceptualizações específicas nos discursos políticos divulgados nas mídias sociais indica novas formas de transmissão do saber e de intercomunicação por meio dos textos. Em razão disso, pode ser enfatizada a perspectiva de Koch (2002), para quem os textos são uma forma de cognição social, uma vez que por meio deles os indivíduos podem estruturar a realidade e o mundo.

Ao contextualizar o corpus aqui presente, tomamos, portanto, uma integração possível entre processos textuais, linguístico-cognitivos e sociais. A nosso ver, tais processos são alguns dentre outros a compor a cognição, ou seja - de acordo com Morato (2017), Salomão (2010), Moura e Gabriel (2012) - assumimos que as explicações para a cognição vão muito além do domínio neurobiológico ou do prisma bioquímico de sinapses, ou de uma faculdade mental e inata, mas se estendem também a motivações de diversas ordens - biológica, cultural, corporal e psicoafetiva, por exemplo.

São discutidos neste trabalho frames evocados em vídeos postados pela equipe de divulgação do atual governador de São Paulo, João Dória, em sua página oficial mantida na plataforma Facebook. A nosso ver, importa compreender como esse conjunto de textos está situado num contexto mais amplo, de autorrepresentação, de promoção de certos valores e projetos para a gestão pública e, de modo geral, de promoção e legitimação de práticas políticas por meio das mídias sociais.

Para as análises, foi constituído um corpus contendo os vídeos publicados nos meses de abril e maio de 2017 e 2018 na referida página de João Dória e, desse total, foram extraídos 16 vídeos para a amostragem - correspondendo a uma distribuição de quatro vídeos publicados em semanas diferentes para cada um dos meses analisados. Aos objetivos do trabalho, interessa (a) identificar frames e conceptualizações presentes nesses dados, bem como (b) discutir seus processos de ancoragem referencial e (c) sua relação com o contexto de divulgação por meio da plataforma de mídia social Facebook.

Consideramos que compreender a ancoragem referencial dos diversos frames evocados nesse conjunto de dados pode ajudar a mostrar como práticas políticas, comunicativas e linguísticas podem se alinhar em um conjunto de estratégias e recursos. Além disso, pode ajudar a compreender como a cognição se situa em práticas linguísticas específicas e como pode se dar sua operacionalização analítica nos estudos do texto (MORATO, 2017, p. 396).

\section{Texto e interação na evocação de frames}

Compreender a língua como prática sociocognitiva requer, internamente à análise linguística, que sejam reconhecidos conhecimentos atinentes à língua, o que leva por diversas vezes nossa análise a 


\section{REVISTA DA ABRALIN}

ser interdisciplinar. O tratamento dado à cognição nos estudos textuais-interativos passou por mudanças a partir dos anos 1980, segundo Morato (2017), muitas das quais influenciadas pelas abordagens de Marcuschi (2002) e Koch (2002; 2004).

Decorre dos trabalhos de tais autores, por exemplo, o enfoque nos textos como processo - e não apenas como produto - nos quais convergem diferentes tipos de conhecimento (KOCH, 2004), de ações em diferentes níveis (MARCUSCHI, 2008) e práticas linguísticas (BENTES; REZENDE, 2014; 2017). A agenda de pesquisa que se estabelece a partir de fundamentos teóricos e metodológicos como esses aumenta o peso epistemológico da interação (MORATO, 2004), da constitutividade cultural e histórica da língua (MARCUSCHI, 2008) e, por conseguinte, dos regimes simbólicos, suas normas e esquemas de conhecimento (MORATO, 2017), para a explicação das práticas linguísticas e as generalizações que se possam fazer em contextos situados.

Como destaca Morato (2017, p. 400), “a concepção de cognição com a qual podemos vincular o legado de Koch e Marcuschi é, assim, de base sociogênica". Ao enfocar diferentes formas de conhecimento e sua relação de mútua constitutividade com a língua e com processos interativos, autores como Koch (2002; 2004), Marcuschi (2002; 2008), Morato e Bentes (2013) assumem que o estudo dos textos e das práticas linguísticas pode oferecer parte possível das respostas para a cognição. A tal esforço analítico procura somar-se este trabalho, assumindo que compõem os fenômenos da cognição processos neurobiológicos, sociogênicos, sistemas experenciais corporais, psicoafetivos, culturais, históricos e, de modo geral, simbólicos e relacionais. Desses processos, pois, a língua participa como constitutiva e não apenas reduzida a um papel instrumental ou puramente comunicacional.

Além de uma concepção sociogênica sobre a cognição e sua relação com a prática linguística, os trabalhos de Koch (2002; 2004), Marcuschi (2008), Morato e Bentes (2013), Morato et al. (2017) acerca dos processos de referenciação em interação possibilitaram observar como estão presentes na língua em uso conhecimentos, motivações, negociações e representações de diversas ordens. De seus estudos decorre a compreensão de que a gestão do tópico discursivo, a construção do texto falado, as estratégias de referenciação, a produção e compreensão de recursos textuais-discursivos como as anáforas indiretas, por exemplo, são processos que envolvem conhecimentos diversos, compartilhados ou não em diferentes graus, mais ou menos negociados, que são representados nas interações ou se projetam sobre elas ao longo da produção e da compreensão dos textos, como modelos de contexto (VAN DIJK, 2012; HANKS, 2008), como modelos cognitivos idealizados (LAKOFF, 2004) ou como frames, por exemplo (MORATO, 2017).

Os frames participariam da prática linguística tanto na produção como na compreensão textuais ao longo das dinâmicas interacionais (MORATO e BENTES, 2013; MORATO et al, 2017). Morato (2017, p. 420) destaca que a perspectiva sociocognitiva na Linguística Textual colaborou para a compreensão de que os frames (entendidos como frames semânticos ou interacionais) participariam como "âncoras sociocognitivas' do processamento textual". A autora relembra o estudo de Marcuschi (2005) acerca das anáforas indiretas e diversos tipos de conhecimento e inferências atuantes na produção e na interpretação de tais recursos, motivo pelo qual Marcuschi se referiu ao processamento anafórico como revelador do "barco textual e suas âncoras". 


\section{REVISTA DA ABRALIN}

Ao retomar a compreensão de Marcuschi (2005) sobre os processos de ancoragem, afirma Morato (2017, p. 420) que as âncoras textuais designam "focos implícitos" ativados durante a significação das expressões referenciais, por meio de processos sociocognitivos como inferências, conhecimentos prévios ou compartilhados, enquadres interativos etc. A partir de tal compreensão sobre o papel das âncoras textuais e sua relação com enquadres conceituais e interacionais, diversos trabalhos têm se dedicado a analisar a ancoragem referencial de frames evocados e reconhecidos em situações de interação - como Morato e Bentes (2013), Martins (2015), Siman (2015).

Neste exercício de análise, assumimos que os frames consistem em domínios de conhecimento e experiência relacionais, mais ou menos dinâmicos e estruturados em diferentes níveis (MORATO et al., 2017; MORATO e BENTES, 2013). Correspondem a "domínios", uma vez que deles fazem parte relações de múltiplos conhecimentos, organizadas sobre conceitos e experiências, e que constantemente se projetam sobre as práticas e interações e/ou são nelas representadas, como mencionado acima, enquanto parte importante para a significação linguística.

Alinha-se aos objetivos do presente trabalho, pois, o estudo da noção de frame em práticas textuais-discursivas e no discurso, de modo geral. De acordo com Siman (2015), tem crescido a quantidade de estudos nos quais esteja em foco especificamente a mobilização de frames e seu uso estratégico no discurso e, como assinala a autora, a partir desse enfoque de pesquisa tais estudos "visam compreender a cognição de indivíduos em uma cultura" (SIMAN, 2015, p. 64).

Os trabalhos de Lakoff sobre frames, sobre modelos cognitivos idealizados (LAKOFF, 2004) e sobre metáforas conceituais (LAKOFF; JOHNSON, 1980) continuam a ser referência para os estudos de frames no discurso, segundo Siman (2015). Ressaltamos, ainda, alguns trabalhos no Brasil cuja fundamentação teórica e cujos passos metodológicos também serviram como base para nossas análises. Morato e Bentes (2013) demonstraram como os frames emergem e são conjuntamente representados ou negociados pelos participantes de uma interação, o que revela a dinamicidade de tais estruturas de conhecimento, em parte organizadas a priori e em parte ligadas à significação e ao andamento das interações. Já Miranda e Bernardo (2013) demonstraram como os frames podem ser um relevante dispositivo analítico, ao se voltarem para discursos sobre as experiências culturais dos indivíduos nos processos escolares de ensino-aprendizagem. Para os autores,

[...] a configuração da rede de frames no discurso faz emergirem as vivencias mais reiteradas e marcantes para os sujeitos na comunidade em foco e finca uma sólida ferramenta como base para a leitura hermeneutica multidisciplinar destas vivencias perspectivadas pelo discurso (MIRANDA e BERNARDO, 2013, p.83).

Também são tomadas como base para o presente trabalho as considerações de Lakoff (2004), sobre os diferentes frames presentes no pensamento político e nas ações levadas a cabo por grupos sociais estadunidenses conservadores e progressistas. Junto a este, ressaltamos ainda as análises de Martins (2015) acerca de frames mobilizados em discursos religiosos neopentecostais de pastores brasileiros. A nosso ver, tais trabalhos auxiliam a compreender como domínios de conhecimento 


\section{REVISTA DA ABRALIN}

específicos se fazem presentes nas práticas linguísticas de campo sociais fortemente estruturados, como são o campo religioso e, no caso do presente trabalho, o campo político (cf. BOURDIEU, 2003).

Os trabalhos brevemente comentados acima, quando tomados em conjunto, exemplificam propriedades diferentes da noção de frame e de sua operacionalização: podem ser abordados como frames cognitivos; interacionais; com enfoque em seu processamento dinâmico e/ou enfocando-se o discurso. Siman (2015) discute características dessas diferentes abordagens para a noção de frame, mencionando, além disso, importantes estudos que as influenciaram² ${ }^{2}$.

No enfoque dado por nós ao discurso, consideram-se os frames mobilizados como parte de um projeto de dizer, como modo de constituir a experiência social ou de representá-la, não raramente de modo reflexivo ou estratégico e contingenciado por aspectos sociais e culturais. E, ao estudaremse frames dinâmicos, enfatiza-se como no decorrer das interações são estabelecidos, mantidos ou modificados os frames, de modo que a significação linguística e os recursos textuais-discursivos se vinculam a essas mudanças (MORATO e BENTES, 2013; MORATO et al., 2017; SIMAN, 2015).

De modo geral, trabalhos como o de Morato et al. (2017), Morato e Bentes (2013) e Miranda e Bernardo (2013) reconhecem, pois, o papel dos estudos produzidos com base na semântica de frames enquanto primeiro momento de trabalho com essa categoria analítica e, a nosso ver, realizam um prolongamento crítico dessas abordagens, na medida em que não reduzem a evocação desses domínios de conhecimento a uma estrutura de construções ancoradas lexicalmente, mas sim compreendem também outros processos (textuais-discursivos) como parte integrante da evocação dos frames. Além disso, para os autores mencionados, não bastaria identificar os frames atuantes em determinados contextos, sendo necessário também explicar como se relacionam esses frames, como perfilam discursos e textos em diferentes níveis.

O presente trabalho se alinha às perspectivas que buscam analisar os frames no discurso, no entanto, sem nos apartarmos de abordagens que permitem entrever como tais domínios de conhecimento são referencialmente ancorados nos contextos específicos de divulgação do discurso político online. A nosso ver, além disso, é preciso aprofundar a compreensão do contexto de produção e de circulação dos frames que estão sendo mobilizados nos discursos políticos selecionados por nós, passando a discutir processos de significação característicos das mídias sociais.

Isso porque a popularização de uma mídia social como o Facebook e seu uso para postagens como aquelas feitas pelo atual governador paulista, João Dória, instaura a possibilidade de discursos políticos de maior alcance, divulgados com maior frequência, mais estrategicamente produzidos e, por isso, que correspondam melhor a domínios de conhecimento e experiência que se possa escolher

2 Como lembra a autora, estudos caudatários da semântica de frames de Fillmore (1976) relacionam-se a uma abordagem que analisa estruturas de conhecimento e ou abstrações (schemas), seu modo de organização no cérebro, relação com o conhecimento linguístico e de mundo, assim como seus modos de representação na língua. Já quando abordados como frames interacionais - acepção usualmente creditada aos trabalhos de Tannen e Wallat (1987) e de Goffman (1974) - ficam enfatizados os sentidos produzidos e frequentemente negociados ao longo das situações comunicativas, sendo os frames nesse caso tomados como enquadres interacionais. Sob essa perspectiva, importariam os modos de reconhecer tais enquadres, por meio de semioses verbais ou não-verbais, bem como os desdobramentos desses enquadres interacionais na prática linguística e na conversação. 


\section{REVISTA DA ABRALIN}

para autorrepresentar-se ou para representar e legitimar práticas políticas. Desse modo, parecemnos conjugados os enfoques no discurso, no aspecto cognitivo e na dinâmica interacional ou contextual para que os frames presentes nesse conjunto de dados possam ser identificados, analisados e contextualizados como pertencentes a práticas linguísticas específicas.

Nas análises a seguir, trataremos dos frames evocados para representar a gestão pública nesse conjunto de vídeos divulgados na página João Dória, enquanto domínios de conhecimento e experiência: (a) ancorados em processos referenciais diversos, (b) alinhados a estratégias comunicativas e funções da mídia social Facebook que permitem uma maior focalização de alguns de seus aspectos.

Ao mencionarmos que estratégias comunicativas perfilam os frames evocados nos dados em questão, o que pressupomos não é a existência de um indivíduo estrategista em sentido mentalista ou volitivo, mas sim um indivíduo cuja prática interacional é plasmada e orientada por diversos sistemas cognitivos, linguísticos e não linguísticos atuantes simultaneamente (cf. REZENDE, 2010). Perspectivação conceitual, intersubjetividade, intencionalidade, ação coor denada para o compartilhamento de intenções, reconhecimento e representação do contexto social e local, inferências, regras pragmáticas e automonitoramento são alguns dos fenômenos atuantes de maneira não caótica nas práticas interacionais como estas discutidas no presente trabalho (TOMASELLO, 2003; MORATO, 2016). Tais formas de ser da cognição parecem, portanto, fortemente atuantes dos dados em questão, que envolvem a divulgação de vídeos de discurso político visando autorrepresentação, promoção e legitimação de ideias - sendo, portanto, finalisticamente orientados por uma complexidade de fatores.

Acerca do serviço de rede social Facebook, é preciso considerar alguns aspectos. Sua fundação, criação e divulgação em 2004 (ARONSON, 2012) como SNS (social network service) aberta a usuários online no mundo todo fez com que, anos depois, fosse possível realizar a divulgação de conteúdos de qualquer natureza para inúmeros indivíduos fora das grandes mídias, como canais de televisão e jornais impressos. Desse modo, na transmissão torna-se possível inclusive a divulgação de discursos políticos, seja por cidadãos, por candidatos a cargos eletivos ou por mandatários já eleitos, que podem encontrar na plataforma um modo de registrar suas ações, de descrever suas propostas, de gerenciar sua representação pública, com vistas a legitimar ${ }^{3}$ ou produzir conteúdo para a popularidade e para futuras campanhas eleitorais, por exemplo.

Por fim, interessa localizar na discussão a trajetória do prefeito João Dória, cujo discurso político será analisado a seguir em uma amostra com dezesseis vídeos publicados nos meses de abril e maio de 2017 e de 2018. Consideramos que tal trajetória importa ao debate sobre a evocação de frames para a gestão pública nas falas do prefeito de São Paulo na medida em que se deu na intersecção

\footnotetext{
3 Além disso, a possibilidade a um ocupante de cargo público, como o atual governador paulista, de transmitir conteúdo por meio da SNS Facebook diminui a necessidade de co-presença dos atores políticos em outros espaços de mídia, espaços nos quais teriam que lidar com perspectivas divergentes, questionamentos de suas ações e desacordos. Com isso, a transmissão de conteúdo via SNS Facebook pode significar a atores políticos como o prefeito João Dória uma possibilidade mais fácil de evocar e construir seus próprios frames para a representação de suas práticas políticas.
} 


\section{REVISTA DA ABRALIN}

entre os campos econômico-empresarial, político e midiático, haja vista que o próprio João Dória se apresenta enquanto proprietário de uma rede de negócios relacionados a eventos e comunicação que busca relacionar o mundo empresarial ao setor público - e se apresenta também como jornalista.

\section{Contexto e ancoragem referencial dos frames em vídeos da página "João Dória"}

Discutimos brevemente aqui a seleção e a organização dos dados, etapas em que procuramos combinar levantamentos quantitativos a uma análise qualitativa sobre os frames. Como subseção, apresentamos os resultados dos levantamentos realizados em postagens dos meses de abril e maio de 2017 na página "João Dória", presente na SNS Facebook e, na subseção seguinte, os resultados dos levantamentos nos dados de 2018, datados dos meses de abril e maio. Consideraremos os diferentes tipos de ancoragem referencial dos frames presentes no conjunto de dados e, posteriormente, relacionaremos os resultados a questões contextuais, como por exemplo o seu funcionamento distinto nos vídeos divulgados a cada ano.

Sobre a seleção e organização dos dados, importa ressaltar que partimos dos passos metodológicos descritos por Miranda e Bernardo (2013). O trabalho das autoras analisa os frames evocados para representar experiências de alunos em contextos educacionais. Combinando a essa metodologia a nosso interesse em um estudo dos frames não necessariamente centrado nas unidades lexicais, procedemos aos seguintes passos:

a) levantamento das publicações na página "João Dória" nos meses de abril e maio de 2017 e nos meses de abril e maio de 2018. Nesse levantamento, classificamos o tipo de postagem (imagem ou vídeo); a presença ou ausência de João Dória nas imagens e nos vídeos; o local em que foram gravados os vídeos;

b) seleção de quatro vídeos publicados em semanas diferentes, no mês de maio (de ambos os anos) e de quatro vídeos publicados nos meses de abril (de ambos os anos), totalizando 16 vídeos.

c) transcrição dos 16 vídeos da amostra, segundo uma notação simplificada daquela utilizada pelo NURC, utilizando o programa ELAN;

d) análise das unidades lexicais no corpus constituído; 


\section{REVISTA DA ABRALIN}

e) busca de frames no dicionário FrameNet BR, nos frames analisados por Martins (2015) e descrição própria dos frames identificados no corpus e não encontrados nessas bases;

f) identificação e anotação dos elementos-frame nos dezesseis vídeos selecionados;

g) discussão sobre a ancoragem referencial dos frames encontrados, relacionando a observação dos frames a questões das abordagens sociocognitivas e discursivas (MORATO et al., 2017).

A escolha por publicações realizadas nos meses de abril e maio de 2017 e 2018 leva em conta que, até o final de março, o governo municipal ainda não havia constituído e divulgado o plano de metas da gestão municipal. O período anterior ao lançamento do plano de metas, conhecido como "os primeiros cem dias" de um mandato, poderia consistir em um intervalo de tempo em que as ações da prefeitura ainda não estivessem bem estabelecidas ou direcionadas em nome de objetivos da gestão. Nesse caso, os meses de abril e maio de 2017 correspondem ao início de uma fase em que as práticas políticas já são orientadas para os objetivos da atual gestão, o que justificaria sua escolha para os levantamentos.

Já a escolha por dados do mesmo período de 2018 se deve ao interesse em observar uma possível transição nas práticas políticas (e, talvez, linguísticas e comunicativas) nos vídeos e textos em questão. Isso porque, segundo as regras para participação em campanhas eleitorais, ocupantes dos cargos de poder executivo deveriam deixar o mandato no caso de concorrer a um distinto cargo (art. $14, \S 6^{\circ}$, da Constituição; art. $1^{\circ}, \S 1^{\circ}$, da LC n $\left.{ }^{\circ} 64 / 90\right)$. Assim, coube ao então prefeito paulistano João Dória deixar o mandato à frente do executivo municipal no dia 10 de abril de 2018, visando a campanha eleitoral ao governo de São Paulo que, segundo a legislação sobre o tema, teve início oficial em 16 de agosto de 2018.

Os dados de abril e maio de 2018, portanto, ocorrem durante as últimas práticas de gestão de João Dória à frente da prefeitura de São Paulo. E, ao mesmo tempo, há a possibilidade de que estejam inseridos em práticas relativas ao que é conhecido como "pré-campanha eleitoral", período não previsto ou reconhecido pela legislação eleitoral e no qual certas práticas políticas e comunicativas são até mesmo vedadas e passíveis de punição, como a retirada de conteúdo ou o pagamento de multas aos partidos e equipes de campanha.

A página João Dória (doravante, "JD") na SNS Facebook conta atualmente (março de 2020) com 2.932.972 perfis cadastrados como seguidores e 2.694.664 perfis cadastrados como "curtidores" ${ }^{4}$, ou seja, perfis ativos na mídia social que não apenas podem acompanhar os textos divulgados como

4 Dados consultados em abril de 2019. Em 2017, apresentava mais de 2,87 milhões de seguidores e 2,77 milhões de curtidores, segundo as medições feitas por nós nos primeiros levantamentos. 


\section{REVISTA DA ABRALIN}

postagens na página, mas acrescentam a ela uma avaliação positiva, se considerarmos o eixo avaliativo "curtir" e "não-curtir" fomentado por essa plataforma de mídia social. Somam-se a isso as aparições que as postagens da página JD podem ter na esfera de visualização de perfis de usuários que não sejam seguidores ou "curtidores" da página.

Essa primeira característica de funcionamento da página e de seu relacionamento com usuários nos parece importante, pois insere os vídeos produzidos por JD numa mídia social de comunicação de massas, não necessariamente de perfis de cidadãos apenas dos colégios eleitorais paulistanos e paulistas, e fornece uma primeira observação do alcance dos conteúdos publicados na SNS Facebook ${ }^{5}$.

Uma funcionalidade como essa nas práticas comunicativas da SNS Facebook abre a possibilidade para que conteúdos com frames específicos cheguem a destinatários também específicos. Com maior possibilidade de escolha dos destinatários, a divulgação de textos em vídeos, como presente na página João Dória, por exemplo, tem a possibilidade de formar não apenas textos eventuais, mas sim uma linha de conteúdo ${ }^{6}$, no sentido de estabelecer um contato mais próximo com grupos de pessoas que já sejam ou não apoiadores e eleitores em potencial.

Não à toa, mídias sociais, como mais recentemente o WhatsApp e anteriormente o Facebook, tornaram-se objeto de análises políticas, científicas e de legislação específica que procurem regulamentar práticas comunicativas por meio dessas plataformas, visando até o momento desacelerar seu enorme potencial de impacto nos processos eleitorais e nos sistemas democráticos como um todo. Ainda assim, novas funcionalidades que vão surgindo em tais mídias, a popularização da venda dos dispositivos eletrônicos que permitem acessá-las, o aumento do tempo médio gasto individualmente na web pelos brasileiros e as facilidades na comparação com a inserção na mídia televisiva ou impressa são fatores que, em certo sentido, tornam tacitamente obrigatório o uso das mídias sociais por lideranças políticas que procurem divulgar suas ações.

\footnotetext{
5 Cabe lembrar que há muita discussão envolvendo as funcionalidades que baseiam os algoritmos de exibição de postagens no Facebook, com a complexidade adicional de que, hoje em dia, tais algoritmos são suscetíveis ao investimento monetário que usuários e administradores de perfis possam fazer em suas redes (MACHADO, 2018).

6 Combinando tais práticas comunicativas e linguísticas às práticas políticas, funcionalidades da SNS Facebook com publicações que evoquem frames específicos fazem com que a formulação de ideais, de projetos, e de grupos de eleitorado, por exemplo, possa se dar de forma mais efetiva. Haja vista que própria mídia social já possui classificações dos indivíduos que podem ser utilizadas (com informações sobre a trajetória e as mais diversas preferências dos usuários), os autores de postagens a serem impulsionadas podem, mediante o pagamento, dispor de um banco de dados ativo e complexo, sem que precisem construir isso por si. Fica aberta, portanto, uma possibilidade comunicativa de grande alcance a ser explorada pelos mais diversos interesses, incluindo aqueles dos agentes do campo político.
} 


\section{Ancoragem referencial dos principais frames no conjunto de dados de 2017}

Para compreender o papel dos vídeos dentre as publicações presentes na página JD, tomaremos alguns dados gerais relacionados às postagens dos meses de abril e maio de 2017. Os levantamentos, feitos a partir da quantificação de diferentes informações presentes nas publicações da página JD nos meses de abril e maio de 2017, nos permitiram reunir certo conjunto de características importantes para a contextualização dos dados com os quais trabalhamos e para compreender os frames evocados e construídos nesses dados.

Nos meses de abril e maio desse ano, não houve dias sem que a página JD publicasse postagens, isto é, todos os dias contaram com ao menos uma publicação na SNS Facebook, totalizando 179 publicações entre imagens e vídeos (com média diária de 2,93 publicações por dia, mais precisamente). Acerca do conjunto total de postagens nos meses de abril e maio de 2017, cabe considerarmos também que o número de vídeos publicados corresponde a $72 \%$, em abril, e a $80 \%$, em maio, do total das publicações feitas na página JD.

A nosso ver, tais dados colaboram para que compreendamos que tais vídeos podem fazer parte de uma prática de comunicação na qual a periodicidade e o número de publicações parecem desempenhar papel fundamental no tipo de conteúdo a ser divulgado. E indicam que, dentro das frequentes postagens responsáveis constantemente por ativar a imagem do prefeito João Dória, os vídeos são tomados como tipo de mídia bastante relevante.

Levando em conta tais aspectos contextuais, foram analisados quatro vídeos publicados em abril (nos dias 05, 13, 20 e 28 de abril) e quatro vídeos publicados em maio (nos dias 02, 09, 15 e 28). Tais vídeos foram gravados em espaços oficiais da prefeitura, em momentos nos quais o prefeito João Dória esteve presente em diferentes ruas de São Paulo e em momentos da visita do prefeito nas cidades de Seul e de Nova Iorque. A partir da transcrição e dos outros passos metodológicos, nesse total de vídeos foram identificados oito diferentes frames. O GRÁFICO 1 lista os frames identificados nos dados de 2017 e quantifica a presença desses frames na amostra de oito vídeos analisados: 


\section{REVISTA DA ABRALIN}

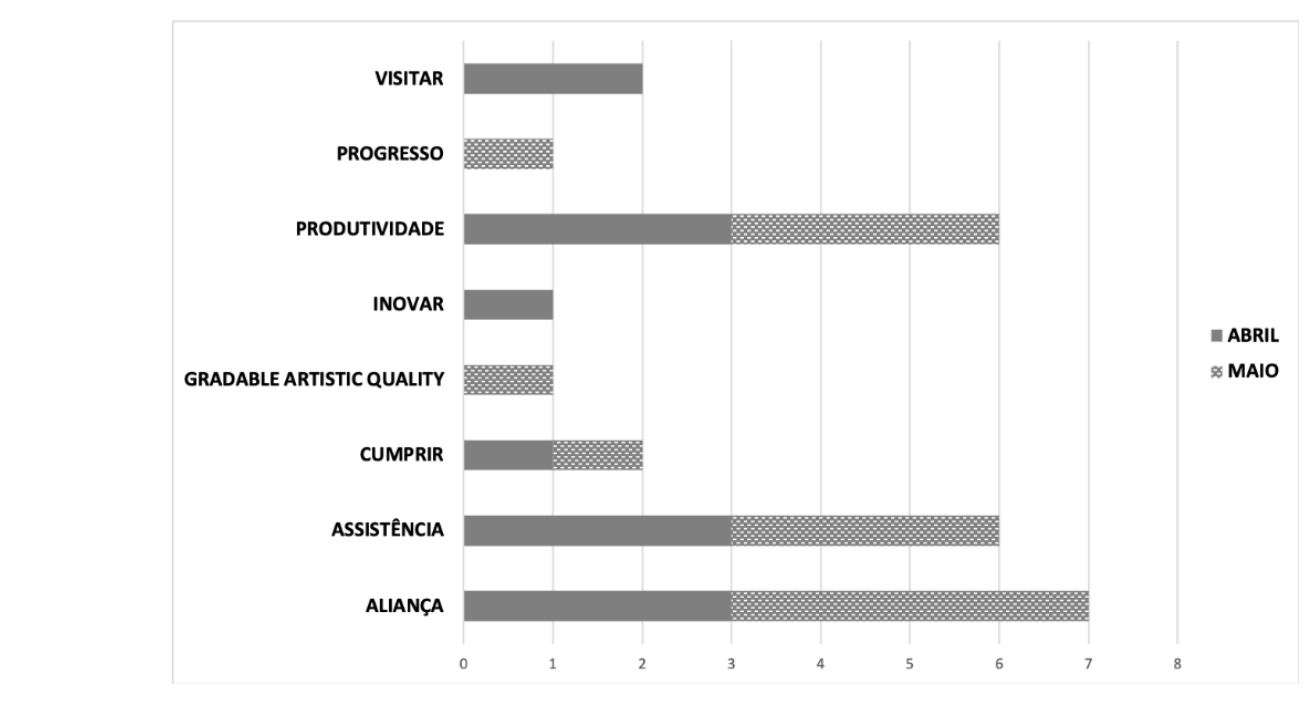

GRÁFICO 1- Frames identificados nos vídeos analisados publicados em abril e maio de 2017 pela página JD no Facebook

Observamos que o frame ALIANÇA é mobilizado em sete dos oito vídeos. Além disso, os frames ASSISTÊNCIA e PRODUTIVIDADE também fizeram parte de um número significativo dos vídeos, evocados em seis vídeos dentre o total. Dando continuidade às análises, trataremos dos processos referenciais que ancoram dois desses frames mais presentes, na tentativa de analisar como foram mobilizados para representar as práticas de gestão pública divulgadas na página JD.

Tomemos primeiramente o frame ALIANÇA e sua presença em 7 (do total de 8) vídeos, como mostra o quadro a seguir.

\begin{tabular}{|c|c|}
\hline $\begin{array}{l}\text { Data de } \\
\text { publicação } \\
\text { dos vídeos: }\end{array}$ & $\begin{array}{l}\text { FRAME: ALIANÇA } \\
\text { Definição (framenet BR): Depois de ter trabalhado separadamente por algum tempo, dois ou } \\
\text { mais indivíduos ou organizações, os Membros, são agora organizados em uma Aliança. Desta } \\
\text { forma, pode-se propor uma Finalidade comum. }\end{array}$ \\
\hline $13 / 04 / 2017$ & $\begin{array}{l}\text { "depois temos um encontro com toda a diretoria da LG que já tem investimentos no Brasil [...] } \\
\text { nosso objetivo } \\
\text { é tecnologia" }\end{array}$ \\
\hline $20 / 04 / 2017$ & $\begin{array}{l}\text { "uma iniciativa da prefeitura de São Paulo com o apoio da ABIA (...) alimentos que serão servido } \\
\text { nos antigos albergues" }\end{array}$ \\
\hline $28 / 04 / 2017$ & $\begin{array}{l}\text { "com um grupo de empresários da Espanha ... e também com o Cônsul geral da Espanha ... em } \\
\text { São-Paulo ... } \\
\text { compondo dois grupos de trabalho" } \\
\text { "empresários da Espanha e profissionais da prefeitura de São-Paulo servidores públicos } \\
\text { trabalhando pelo bem da nossa cidade" }\end{array}$ \\
\hline $02 / 05 / 2017$ & $\begin{array}{l}\text { "já estamos [prefeitura e catedral anglicana] pensando na segunda creche e também em um } \\
\text { CTA para as pessoas em situação de rua [...] as forças do bem se unem para melhorar a cidade" }\end{array}$ \\
\hline
\end{tabular}




\section{REVISTA DA ABRALIN}

\begin{tabular}{|c|c|}
\hline $09 / 05 / 2017$ & "essas dez empresas que estão colaborando (...) para os programas de saúde pública" \\
\hline $15 / 05 / 2017$ & $\begin{array}{l}\text { "buscando novos investidores que acreditam no Brasil ... e acreditam nesse novo projeto [...] } \\
\text { com a presença do A. B. que é presidente do banco, com vários de seus diretores e grandes } \\
\text { investidores americanos e brasileiros" }\end{array}$ \\
\hline $28 / 05 / 2017$ & $\begin{array}{l}\text { "ao lado de uma equipe formidável de grafiteiros de artistas de rua viemos inaugurar" } \\
\text { o primeiro MAR" }\end{array}$ \\
\hline
\end{tabular}

QUADRO 1 - Frame ALIANÇA nos dados de 2017 e segmentos correspondentes Fonte: elaborado pela autora.

O Quadro 1 contém os segmentos relativos a ALIANÇA em cada um dos vídeos nos quais esse frame foi identificado, nos meses de abril e maio. Além disso, a partir da definição do frame tal como consultado na framenet BR, foram destacados os segmentos relativos aos elementos-frame que compõem o frame ALIANÇA.

Ao considerarmos que ALIANÇA corresponde a uma união entre diferentes entidades como membros, em busca de uma finalidade em comum, observamos diferentes recursos linguísticos compondo esse frame. Por exemplo, há diferentes verbos ("trabalhando", "colaborando", "compondo", "se unem") ocupando os elementos-frame que correspondem à ideia de "aliança", propriamente (segmentos destacados em verde). No entanto, para além dos verbos, há também expressões compostas por preposições que são capazes de indiciar a participação de dois membros em uma atividade em comum (como podemos ver nos segmentos "ao lado de", "com a presença de"). Além disso, é possível considerar que o referente "investidores" pode ajudar na evocação do frame ALIANÇA, uma vez que a ideia de "investir" pressupõe a articulação entre diferentes entidades e que o morfema final, indiciador de agentividade ("investidores"), pode se ligar aos agentes membros da aliança em questão.

Os elementos-frame Membros da aliança (destacados em amarelo) são facilmente identificados, pois são especificamente mencionados pelo prefeito João Dória em expressões referenciais por vezes longas, como descrições definidas compostas por um nome núcleo e diferentes modificadores ("um grupo de empresários da Espanha", "uma equipe formidável de grafiteiros de artistas de rua"). A partir dos exemplos acima, também é possível notar diferentes segmentos compondo os elementosframe Finalidade (destacados em azul), em posição de complemento nominal ("nosso objetivo é tecnologia") ou complemento verbal ("na segunda creche", "e também em um CTA").

Consideramos que um exemplo representativo da evocação do frame ALIANÇA nos dados analisados pode ser encontrado no segmento "as forças do bem se unem para melhorar a cidade". Nesse segmento, as práticas de gestão pública são ancoradas figurativamente, ao levarmos em conta as alianças e parcerias que a prefeitura é capaz de fazer com entidades (públicas e privadas). Nesse sentido, a expressão "as forças do bem" refere-se aos membros da aliança, incluindo a prefeitura, por meio de um domínio-fonte de oposição entre "o bem e o mal".

Observemos agora o Quadro 2QUADRO 2, no qual estão organizados dados relativos ao frame ASSISTÊNCIA, presente em seis dos oito vídeos analisados. 


\section{REVISTA DA ABRALIN}

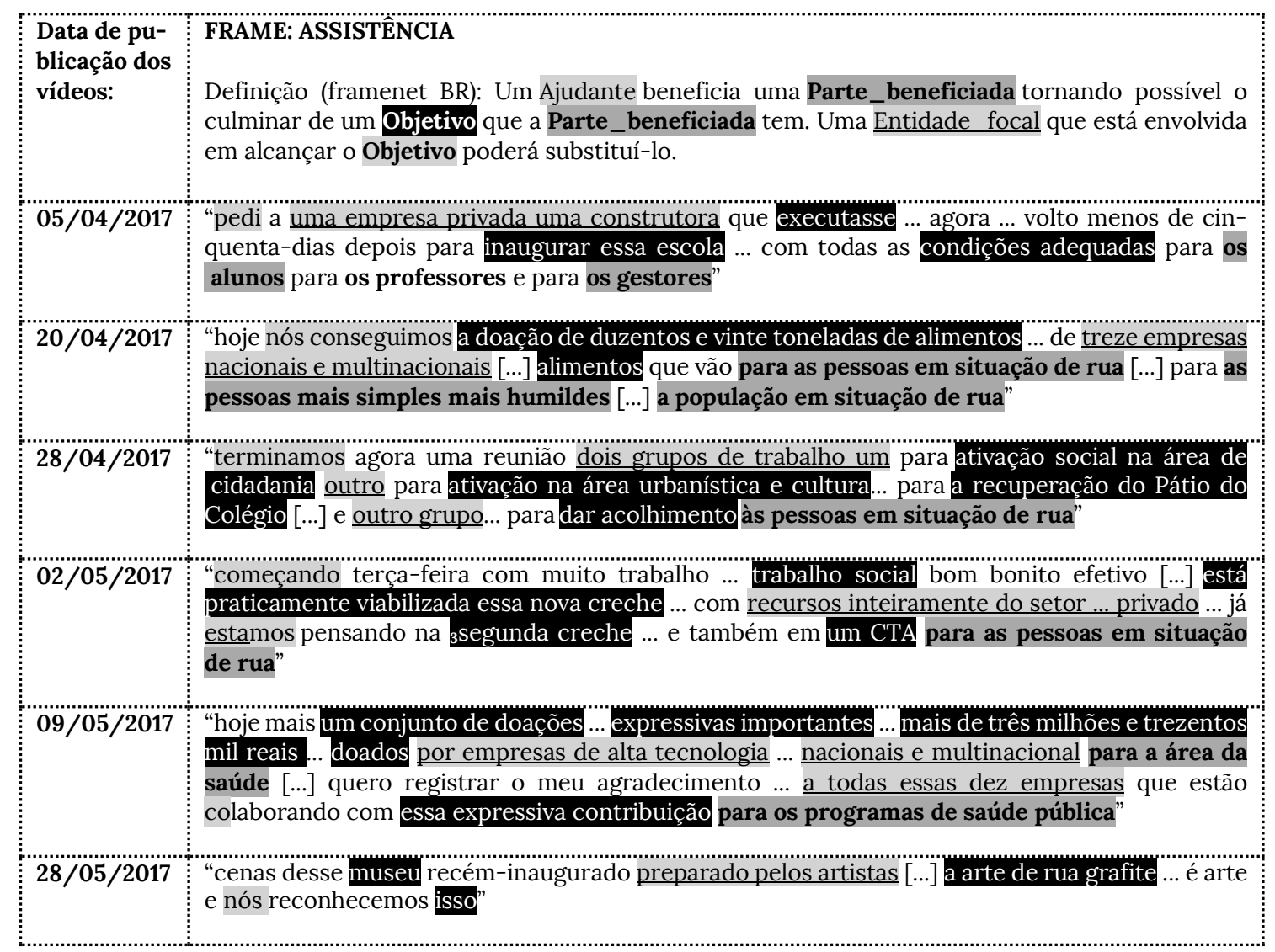

QUADRO 2 - Frame ASSISTÊNCIA nos dados de 2017 e segmentos correspondentes. Fonte: elaborado pela autora

Os segmentos foram destacados em diferentes cores de acordo com os elementos-frame aos quais corresponderiam. Por meio dos dados acima, é possível notar que o elemento-frame Ajudante (destacado em amarelo) pode ser identificado por diferentes verbos ("pedi", "terminamos", "reconhecemos", "nós conseguimos"). Tais verbos presentes na fala de JD geralmente não são acompanhados da explicitação dos agentes em posição de sujeito. Contudo, é possível considerar que os verbos conjugados em plural explicitam as ações desempenhadas pela prefeitura, como equipe composta por mais de um indivíduo, na conquista de um Objetivo. Assim, os elementos-frame Objetivos corresponderiam a diferentes realizações executadas por Entidades-focais em função de uma ação inicial da prefeitura.

Fazem parte dos segmentos relacionados aos Objetivos diferentes expressões referenciais que designam realizações mencionadas pelo prefeito João Dória ("ativação na área urbanística e cultura", "recuperação do Pátio do Colégio", "essa nova creche", "um conjunto de doações expressivas importantes” etc). Nos trechos acima, o elemento-frame Parte-beneficiada também pode ser facilmente relacionado aos diversos segmentos, se levarmos em conta as expressões referenciais presentes em sintagmas preposicionais, que indicam os destinatários da assistência ("para as pessoas mais simples $e$ humildes", "para a área da saúde", "às pessoas em situação de rua"). Por fim, é possível notar diferentes 


\section{REVISTA DA ABRALIN}

formas de evocação do elemento-frame Entidade-focal nesse conjunto de dados, ora em segmentos que ocupam função de agente da passiva ("preparado pelos artistas", "dados por empresas de alta tecnologia"), ora em segmentos com função de complemento ou adjunto introduzido por preposições ("pedi a uma empresa privada", "conseguimos a doação de treze empresas nacionais e multinacionais").

\section{Ancoragem referencial dos frames no conjunto de dados de 2018}

O conjunto de publicações de abril e maio de 2018 apresenta diferenças quando comparado ao anterior: o número total de postagens e sua distribuição nos meses de abril e maio de 2018 diminuiu e apresentou maior inconstância, na comparação com os dados de 2017, totalizando 93 publicações entre vídeos e imagens. Durante os meses analisados, em 16 dias desse total, não houve postagens na página JD, situação bastante diferente do ano anterior, quando ao menos uma postagem foi feita a cada dia. Com isso, a média de postagens passou de 2,93 publicações por dia em 2017 para 1,52 publicações por dia em 2018 (quando analisados os meses de abril e maio).

Em abril de 2018, os vídeos corresponderam a 76\% das publicações feitas na página JD, enquanto as imagens corresponderam a $24 \%$. Esse número se assemelha às atividades de abril do ano anterior na página, apesar de indicar uma queda em comparação a 2017 - quando as imagens corresponderam a 28\% do total de publicações. Já durante maio de 2018, é possível notar uma mudança mais significativa, visto que a proporção entre imagens e vídeos praticamente se igualou, com os vídeos correspondendo a $51 \%$ das publicações e as imagens a $49 \%$ do total de postagens.

A queda no número de publicações parece revelar uma mudança no entendimento do papel das práticas comunicativas e linguísticas no Facebook para representar ou compor as estratégias comunicativas de João Dória. Além disso, cabe lembrar que tal período em 2018 consistia num momento de transição em que o então prefeito João Dória, visando concorrer ao cargo do executivo estadual e por exigência da legislação eleitoral, deixou o mandato à frente da prefeitura paulistana para que se tornasse elegível no pleito de seis meses depois. Com isso, os dados de 2018, sobretudo os de abril, correspondem ao período em que João Dória deixou o cargo na prefeitura para preparar a estrutura da campanha eleitoral que começaria oficialmente em 16 de agosto de 2018.

Passando à análise dos frames evocados e construídos no conjunto de dados de 2018, também é possível observar mudanças. Nos dados de 2018 - organizados no

GRÁFICO 2 - foram evocados onze diferentes frames nos vídeos publicados no período em questão, o que corresponde a uma variabilidade maior na comparação com o ano anterior. 


\section{REVISTA DA ABRALIN}

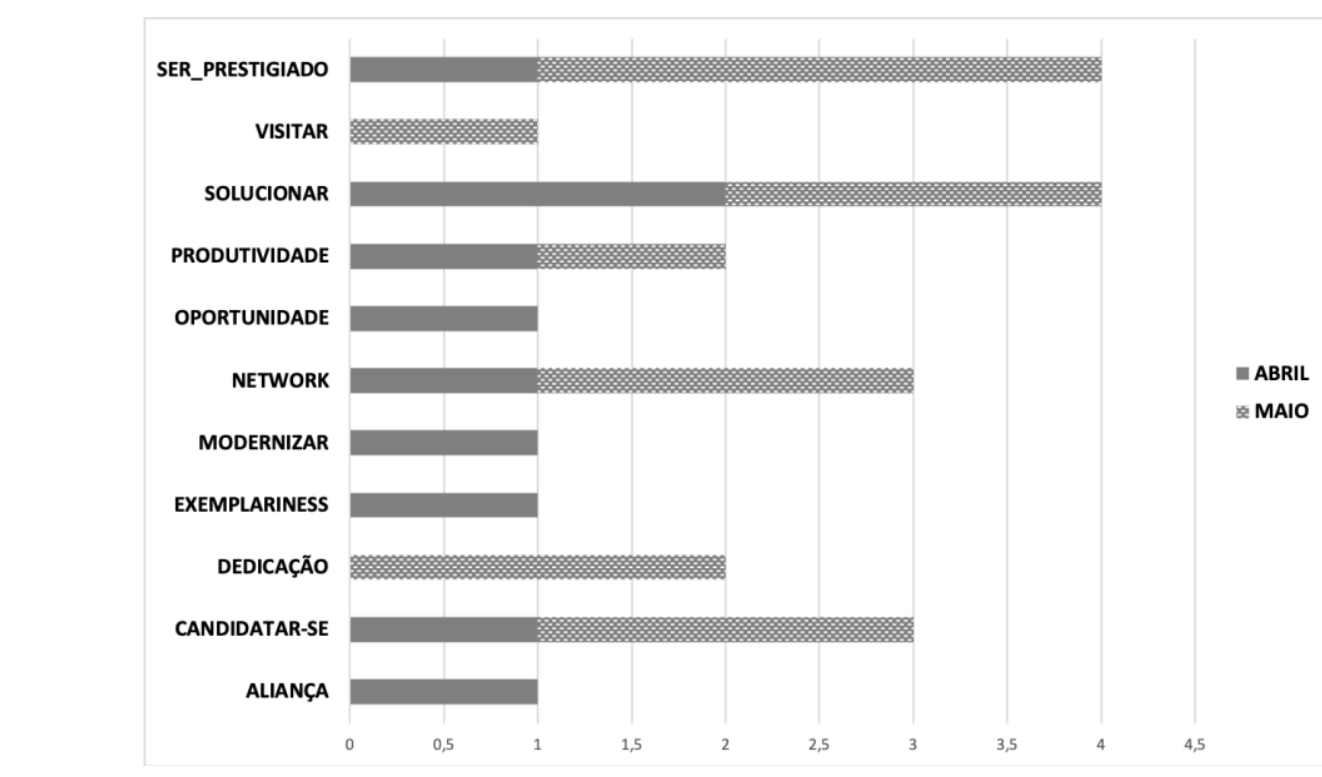

GRÁFICO 2- Frames identificados nos vídeos analisados publicados em abril e maio de 2018 pela página JD no Facebook Fonte: elaborado pela autora.

A presença de alguns dos frames, na amostra de 2018, concentrou-se em apenas um dos meses, enquanto a presença de outros se dividiu mais ou menos igualmente entre vídeos de ambos os meses. Nos meses de abril e maio de 2018, os frames SOLUCIONAR e SER_PRESTIGIADO foram os que mais estiveram presentes nos vídeos da amostragem, e fizeram parte de 4 do total de 8 vídeos analisados neste ano.

Dando continuidade às análises, trataremos dos processos referenciais que ancoram esses frames mais presentes, na tentativa de analisar como foram mobilizados para representar e compor as práticas políticas da página JD em 2018. O quadro abaixo ilustra exemplos da presença do frame SOLUCIONAR, presente na metade dos vídeos da amostragem de 2018 e igualmente distribuído entre vídeos de abril e maio. Vejamos:

\begin{tabular}{|c|c|}
\hline $\begin{array}{l}\text { Data } \\
\text { vídeo }\end{array}$ & $\begin{array}{l}\text { Frame: SOLUCIONAR: } \\
\text { Definição (da autora): visando mudar uma situação na qual existe um ou mais Problemas uma } \\
\text { ou mais parte Solucionadora toma Decisões ou realiza Ações que envolvam as diferentes } \\
\text { Partes-envolvidas no Problema. As Decisões ou Ações podem apresentar inclusive uma } \\
\text { Vantagem em comparação à situação inicial. }\end{array}$ \\
\hline $04 / 04 / 2018$ & $\begin{array}{l}\text { “olá/ Benjamin Steinbhuch ahn:: C.E.O. ahn do conselho do Jóquei Clube de São } \\
\text { Paulo... e eu apresentamos hoje o novo projeto do Parque do Jóquei... [...] eh/ o Jóquei } \\
\text { preservará as áreas relativas aos seus associados... ao Prado ... portanto as... corridas mas } \\
\text { teremos no Parque do Jóquei... um espaço aberto à população pra que todos que vivem aqui... } \\
\text { em torno ou os que residem... longe... que poderão vir aqui... para desfrutar do Jóquei Clube } \\
\text { de São Paulo [...] uma boa solução... pro Jóquei Clube... pra comunidade que reside em torno }\end{array}$ \\
\hline
\end{tabular}




\section{REVISTA DA ABRALIN}

\begin{tabular}{|c|c|}
\hline & $\begin{array}{l}\text { do Jóquei... e pra cidade de São Paulo -- repito --... sem custo nenhum pra cidade... nós vamos } \\
\text { ganhar mais um lindo parque [...]" }\end{array}$ \\
\hline 28/04/2018 & $\begin{array}{l}\text { “olá pessoal encerramos agora... uma ampla reunião com o setor de agronegócios aqui... do } \\
\text { estado... de São Paulo sob a liderança do Roberto Rodrigues... ex-ministro da agricultura } \\
\text { e uma das figuras mais respeitáveis do mundo do agro nós/ ahn:: discutimos } 10 \text { problemas } \\
\text { do agro em São Paulo... as soluções... as alternativas para a valorização do setor... a ativação } \\
\text { econômica geração de emprego geração de renda e soluções... que possam ser aplicadas no } \\
\text { âmbito do governo do estado de São Paulo [...] }\end{array}$ \\
\hline $18 / 05 / 2018$ & $\begin{array}{l}\text { "o que vocês vão ver agora... é um dos grupos de trabalho... de estudos... para a nossa } \\
\text { proposta de governo... para o estado... de São Paulo... estamos reunindo pessoas que são } \\
\text { capacitadas... experientes... vividas... no setor privado no setor público...[...] para fazer- } \\
\text { mos uma campanha propositiva... e levar a você... e a todos que estão no nosso estado... } \\
\text { propostas concretas efetivas inovadoras... e ao mesmo tempo... solucionadoras... dos nossos } \\
\text { problemas... acelera"” }\end{array}$ \\
\hline $26 / 05 / 2018$ & $\begin{array}{l}\text { "[...] a caminho de Franca... no interior de São Paulo... para compartilhar com as pessoas/ } \\
\text { com a população de Franca e as suas principais lideranças... políticas e empresariais... } \\
\text { problemas... e soluções... e assim... passo a passo... visitando todo o estado de São Paulo com } \\
\text { você... acelerando" }\end{array}$ \\
\hline
\end{tabular}

QUADRO 3 - Frame SOLUCIONAR na amostragem de dados de 2018 e segmentos correspondentes Fonte: elaborado pela autora.

O Quadro 3 contém excertos relativos ao frame SOLUCIONAR, descrito por nós após a identificação dos elementos em comum que permitem ver sua estruturação e ancoragem. Consideramos, pois, que neste frame são representadas Ações ou Decisões de uma parte Solucionadora, em contato com diferentes Partes_envolvidas, para mudar uma situação que representa um Problema. Além disso, as decisões e ações realizadas podem inclusive significar uma Vantagem em comparação à situação inicial de problema.

São evocados inicialmente como parte Solucionadora diferentes entidades, como a própria prefeitura na figura do então prefeito JD e representantes de associações com quem foi preciso negociar (“B. S., C.E.O. do conselho do Jóquei Clube de São Paulo e eu”). Já em um segundo momento, no qual JD já havia deixado o cargo de prefeito, os elementos-frame acerca de partes Solucionadoras passam a evocá-lo (por meio de morfemas que indicam JD, como em "encerramos") junto a representantes de setores (como nos segmentos "sob a liderança de R.R., ex-ministro da agricultura...", "pessoas que são capacitadas, experientes, vividas") que decidem se reunir para propor soluções - que seriam levadas ao pleito eleitoral de 2018. Há ainda exemplos no qual a Parte_Solucionadora é evocada por meio de expressões que se referem ao deslocamento de JD ("a caminho de Franca... no interior de São Paulo") para eventos dos quais participaria para "compartilhar" soluções com a população e lideranças locais.

São evocadas como Ações e Decisões os projetos já acordados (como nos segmentos relativos ao "Parque do Jóquei") ou decisões de criação de grupos de trabalho e de propostas que levarão à resolução de problemas (por exemplo, "uma ampla reunião com o setor do...", "um grupo de trabalho, 


\section{REVISTA DA ABRALIN}

de estudo, para a nossa proposta de governo"). Além daquilo já projetado ou inicialmente constituído, é evocado como exemplo de Ações ou Decisões que compõem o frame SOLUCIONAR o próprio compartilhamento coletivo de soluções feito entre JD e outras pessoas (como mostra o segmento "compartilhar com as pessoas problemas e soluções"), de modo que o próprio ato de "compartilhar soluções" também possa ser "solucionar".

Como segmentos relacionados às Partes_envolvidas, são evocados aqueles com quem foi necessário dialogar para chegar às soluções ("o setor do agronegócio") ou aqueles a quem a solução atingirá $^{7}$ (como nos segmentos que indicam os "associados" do Jóquei, "todos que vivem aqui em torno ou que residem longe", "a cidade de São Paulo", "todos que estão no nosso estado", "a população de Franca, suas principais lideranças políticas e empresariais").

Cabe destacar, por fim, os diferentes modos de evocar o Problema em questão: ora mais generalizadamente, nos dados relacionados ao mês de maio (como mostram os segmentos genéricos "nossos problemas" ou simplesmente "problemas"), ora mais especificamente (como mostra o segmento "os problemas do Agro em São Paulo") e ora sem mencionar o problema, no vídeo de 04 de Abril em 2018. Nesse caso em que foram evocados como Parte_Solucionadora tanto JD como o C.E.O. do Jóquei Clube, a prefeitura à época acionava judicialmente o próprio Jóquei Clube por conta de dívidas em impostos municipais e - apesar ou em função da questão judicial - o elemento_frame Problema não foi mencionado no vídeo feito por JD com a presença e participação do C.E.O. do Jóquei Clube. Como elemento_frame relacionado a esse mesmo vídeo, evoca-se como Vantagem que a solução apresentada não representaria "custo nenhum pra cidade".

Observemos agora o Quadro 4, que exibe exemplos relativos ao frame SER_PRESTIGIADO ${ }^{8}$, presente em quatro do total de oito vídeos analisados na amostragem de 2018.

\begin{tabular}{|c|c|}
\hline $\begin{array}{l}\text { Data da pu- } \\
\text { blicação do } \\
\text { vídeo: }\end{array}$ & $\begin{array}{l}\text { Frame: SER_PRESTIGIADO } \\
\text { Definição (nossa): uma parte Receptora, agente ou evento, recebe prestígio dado por um } \\
\text { Agente, por meio de Ações que afetam positivamente o receptor ou por meio de Atributos dos } \\
\text { agentes que se estendem ao receptor durante contato entre as partes. }\end{array}$ \\
\hline $21 / 04 / 2018$ & $\begin{array}{l}\text { "olha aí pessoal eu estou aqui em Campinas... olha a quantidade de gente que tem aqui... gente } \\
\text { boa gente de coração... gente que quer o bem de São Paulo... eu estou muito feliz de... estar aqui } \\
\text { em Campinas... obrigado pessoal todos da região metropolitana de Campinas... por esse apoio } \\
\text { e esse carinho/ obrigado pessoal" }\end{array}$ \\
\hline $03 / 05 / 2018$ & $\begin{array}{l}\text { lha aí pessoal nós estamos aqui em Mogi das Cruzes olha o carinho das pessoas.... } \\
\text { mo das pessoas que estão aqui... muito obrigado Mogi das Cruzes pela forma tão } \\
\text { om que eu fui recebido aqui... um carinho de jovens... senhoras senhores... militan }\end{array}$ \\
\hline
\end{tabular}

7 Ressalte-se que algumas dessas Partes_envolvidas podem também ocupar o papel de outros elementos-frame, sendo a um só tempo Parte_solucionadora e Parte_envolvida beneficiária das soluções (como o "setor do agronegócio" e "a população de Franca, suas principais lideranças...").

8 As definições do frame SER_PRESTIGIADO também foram feitas por nós após a identificação de estruturações e ancoragens comuns nos vídeos analisados. 


\section{REVISTA DA ABRALIN}

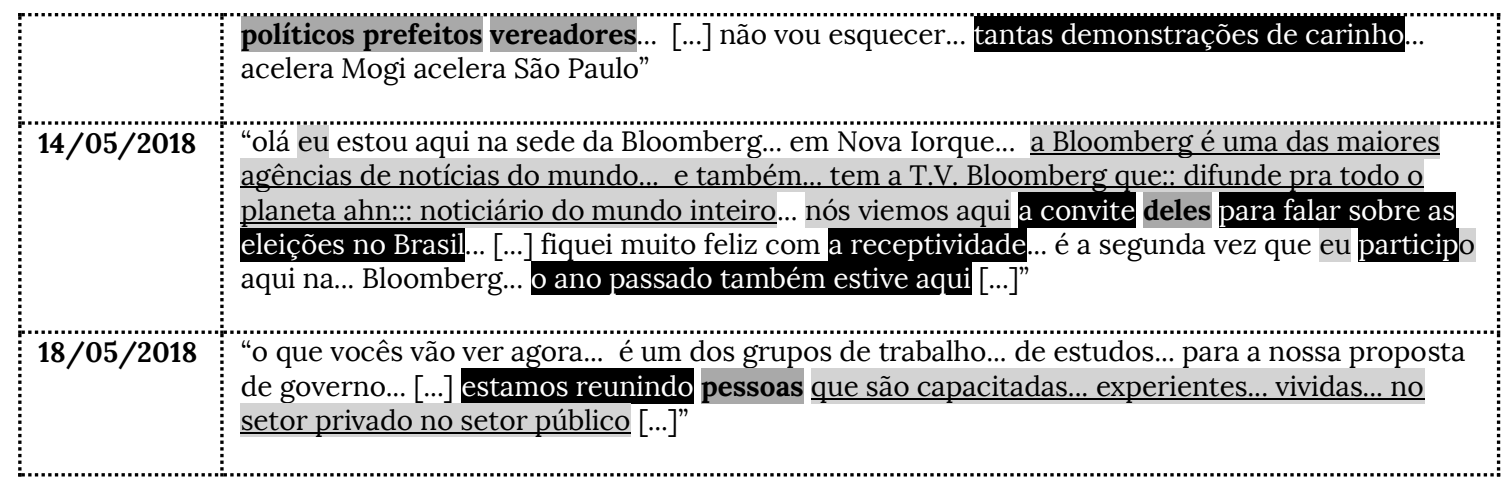

QUADRO 4 - Frame SER_PRESTIGIADO na amostragem de dados de 2018 e segmentos correspondentes. Fonte: elaborado pela autora

O frame SER_PRESTIGIADO descreve uma parte Receptora que é prestigiada por um Agente, seja por meio de Ações do Agente que a afetem positivamente, seja por meio de Atributos do Agente que se estendem ao Receptor em consequência do contato entre ambos.

Da evocação do frame SER_PRESTIGIADO nos dados, participam pronomes ("eu estou aqui...", "nós estamos aqui...", "nós viemos aqui...", "eu participo aqui..."), morfemas e expressões referenciais que indicam JD e sua equipe como parte Receptora de prestígio. Por sua vez, são evocados como Agentes, em parte das ocorrências desse frame, os grupos de pessoas presentes nos eventos dos quais participa em diferentes cidades, evocadas pelos nomes núcleos ("gente", "as pessoas", "senhoras", "senhores", "militantes", "políticos", "prefeitos", "vereadores") de expressões referenciais, na maioria das vezes, mais extensas.

Nesses casos, chama atenção tanto a variabilidade de nomes que são evocados como Agentes que prestigiam a parte Receptora, JD, quanto o tipo de modificador que qualifica, sempre positivamente, esses Agentes e perfis sociais. Com isso, os modificadores dessas expressões referenciais passam a ser evocados como Atributos positivos de tais perfis sociais ("boa", "de coração", "que quer o bem de São Paulo", "que são capacitadas", "experientes", "vividas no setor privado, no setor público").

Por sua vez, as Ações empregadas por tais Agentes e que confeririam prestígio ao Receptor são evocadas pela intensidade da presença desses grupos nos eventos feitos por JD ("a quantidade de gente que tem aqui", "tantas demonstrações de carinho") e pelo modo positivamente afetuoso com que os Agentes participam de seus eventos ("esse apoio", "esse carinho", "o entusiasmo", "forma calorosa com que fui recebido aqui", "tantas demonstrações de carinho" etc). Esses exemplos representam e compõem práticas políticas segundo as quais, à medida que seja positivamente apoiado por perfis sociais variados e numericamente grandes da massa populacional, mais prestígio político junto aos grupos de eleitorado JD poderia ter.

Além de grupos sociais, instituições também podem ser evocados como Agentes, a exemplo da empresa estadunidense de mídia, Bloomberg, que é mencionada por JD. Nesse caso, o segmento responsável pela evocação desse elemento_frame não está na expressão referencial, mas sim na informação mobilizada por JD para justificar sua presença na sede do grupo comunicacional: " a convite 


\section{REVISTA DA ABRALIN}

deles". Ocorre neste exemplo maior focalização nos Atributos desse Agente, por meio de uma predicação e com informações mais longas, como mostra o segmento "a Bloomberg é uma das maiores agências de notícias do mundo...". Como efeito disso, configura-se uma ativação de elementos_frame em que o convite para participar da programação de uma empresa comunicacional com esses atributos significa prestígio (pode ter se dado em função do prestígio já adquirido por JD ou então passa a lhe conferir prestígio).

São modos de ancorar o frame SER_PRESTIGIADO também as Ações de reunir e contar com uma equipe política de Agentes com Atributos diversos e já prestigiados (como mostram os segmentos "pessoas que são capacitadas, experientes, vividas, do setor público e privado"). Nesse caso, é possível dizer que os Atributos desses Agentes se estendem a JD no momento em que decidem formar uma equipe, envolvendo a ideia de que a capacidade de JD em reunir pessoas de tais Atributos como membros de sua equipe significa ser reconhecido por tais Agentes, o que também lhe conferiria prestígio.

\section{Resultados das análises}

Os frames evocados nesses dados demonstram conceptualizações específicas sobre as práticas políticas de JD. Como observamos, em 2017, a conceptualização das práticas políticas esteve ligada à ideia de governar como fazer alianças com grupos diversos, fornecer ou promover assistência à população e governar com produtividade, de modo que a velocidade, a administração do tempo e a quantificação de compromissos e resultados também foram evocados como índices importantes (como mostram os elementos-frame ligados a tais ideias).

Já em 2018, a conceptualização das práticas políticas esteve mais voltada para a ideia de que governar é solucionar e envolve ser prestigiado. Interessa perceber, neste caso, que os frames mais presentes se relacionam tanto com as práticas políticas de JD enquanto ocupante do cargo de prefeito quanto com a campanha eleitoral da qual JD viria a participar. Com isso, evocar o frame SOLUCIONAR pode equivaler a um modo de retomar os resultados como prefeito e elaborar referências à capacidade de solucionar problemas, fatores que podem ser considerados para um possível voto em JD nas eleições seguintes.

Nesse sentido, pode ser explicada também a presença do frame SER_PRESTIGIADO nos dados do período em que JD já havia deixado a prefeitura, pois após o mandato como prefeito seria possível evocar ideias e fatos tanto sustentando que JD adquiriu prestígio no período em que esteve com o mandato, como mostrando que tal prestígio poderia corresponder a um diferencial positivo para si na campanha eleitoral seguinte. Desse modo, os dados de 2018 de fato mostram conceptualizações voltadas tanto para as práticas políticas de governar quanto para aquelas ligadas a candidatar-se ou concorrer. 


\section{REVISTA DA ABRALIN}

De acordo com os dados das amostras de 2017 e de 2018, é possível concluir algumas características importantes sobre a ancoragem referencial dos frames identificados. Diferentes níveis linguísticos e processos referenciais são responsáveis pela evocação dos frames, dentre os quais destacamos:

a) a participação de uma base lexicográfica, pois de fato os substantivos, verbos, morfemas e preposições participam da evocação dos frames em questão;

b) a distribuição dos frames em enunciados inteiros, haja vista que um mesmo frame só completa sua estrutura ao final do enunciado, ou seja, há frames sobrepostos que são evocados, momentaneamente dão lugar a outros e, posteriormente, são retomados ao final do enunciado;

c) a importância de identificar os frames levando em conta um nível textual-interativo, dado que a situação comunicativa e a função textual de um segmento são importantes, por exemplo, para analisar o emprego de segmentos que contêm atenuadores e inseridos num contexto específico, no caso, de gestão pública (como no uso das expressões "encontro" e "com o apoio de" ao evocar a ideia de parceria público-privada e, com isso, o frame ALIANÇA).

d) a participação de aspectos pragmáticos e de normas e valores específicos na identificação dos frames, como ocorre no caso do frame SER_PRESTIGIADO, por exemplo, e de seus elementosframe. Nesse caso, identificar ações que podem conferir prestígio, e por meio de quais atributos se confere prestígio, envolve o compartilhamento de um sistema de conhecimentos, normas e valores que têm papel-chave.

Além dos próprios frames, o entrelaçamento entre os elementos-frame pode ser mobilizado para discutir os domínios de conhecimento e as formas simbólicas e ideológicas ${ }^{9}$ que foram evocadas nos dados analisados. Isso porque a seleção e a frequência de um tipo de aliança (entre a prefeitura e empresas, investidores e associações compondo os elementos-frame de maior agentividade) pode ajudar a indicar uma posição mais específica de JD no campo político ${ }^{10}$ e de seu discurso no trabalho de divulgação de formas simbólicas.

9 Embora não esteja no escopo do trabalho uma relação micro-macro entre frames e sistemas simbólicos e ideológicos mais amplos, para além da perspectiva textual-interativa aqui assinalada, consideramos que tais textos são também objetos e/ou formas simbólicas de elaboração e circulação de ideologias (BOURDIEU, 2003), de modo que sua divulgação pode corresponder a mais um meio de realização do trabalho ideológico e, assim, de amplas disputas simbólicas de poder.

10 A frequência da evocação de elementos-frame que designam representantes setoriais parece mostrar, ainda, que os dados analisados enfocam JD por meio de seu capital social (BOURDIEU, 2003). No conjunto de dados, esse tipo de capital, derivado do cargo 


\section{REVISTA DA ABRALIN}

\section{Encaminhamentos}

A descrição analítica dessas conceptualizações e das formas de ancoragem referencial dos frames são passos importantes para uma compreensão mais aprofundada e interdisciplinar das práticas comunicativas do discurso político nas mídias sociais. Isso porque descrever como são instanciadas pela língua as conceptualizações em andamento nos discursos políticos permite aos indivíduos uma maior reflexividade sobre os "princípios de visão e de divisão do mundo" (BOURDIEU, 2003) que estão sendo colocados em jogo.

Os frames identificados por nós que foram evocados para compor o discurso político nesse conjunto específico de dados podem ajudar ainda a verificar se estão sendo construídos novos frames por meio das práticas comunicativas online de João Dória. Por exemplo, a associação reiterada entre frames ligados ao campo econômico-empresarial e aqueles ligados ao campo político pode colaborar para construção de domínios de conhecimento e experiência em que políticos passem a ser "políticos-gestores", ou para que os domínios de conhecimento relativos à gestão empresarial passem a fazer parte da política cada vez mais ordinariamente. Assim, a expressão comumente utilizada para se referir a JD como um "político-gestor" parece resultar também dos frames presentes em suas práticas linguísticas e comunicativas nas mídias sociais - e não apenas de uma trajetória profissional ou pessoal anterior, ou de suas afinidades e decisões nas ações políticas stricto sensu.

Funcionalidades próprias de mídias sociais como o Facebook - plataforma de propriedade privada sobre a qual até 2018 não incidia regulação alguma acerca de práticas de campanha política permitem o registro das relações que compõem o capital social de JD, bem como permitem visualizar dados posteriores de como seus vídeos e discursos políticos foram recebidos pelos usuários da rede ligados a seu perfil. Além disso, funcionalidades do Facebook permitirão que os vídeos postados por JD e sua equipe cheguem a perfis específicos de usuários, ajudando, por exemplo, a desenhar e atingir perfis de recepção e de eleitorado para as formas simbólicas e ideológicas que circulam pelas mídias sociais (MACHADO, 2018).

Com isso, os frames evocados exemplificam ações perspectivadas, motivadas, contextualizadas, nas quais comparece em diferentes níveis a reflexividade (MORATO e BENTES, 2017) e, quando evocados nos vídeos a serem divulgados nas mídias sociais, de fato parecem participar da elaboração de estratégias comunicativas. A combinação entre (a) uso da SNS Facebook, (b) as publicações na página JD e (c) os principais frames evocados demonstra haver um grande alinhamento entre as práticas (políticas, comunicativas e linguísticas), passível de ser observado quando nos voltamos para a dimensão sociocognitiva da linguagem e dos processos textuais-discursivos.

Esperamos que o presente trabalho possa colaborar com a apresentação de um percurso analítico no qual esteja exemplificada uma abordagem possível para a ancoragem referencial dos frames

de prefeito e evocado nos momentos de preparação para uma nova eleição, representa relações sociais que conferem poder simbólico e político a JD individualmente, mas que também poderiam ser convertidas em ações conjuntas que beneficiariam a população. 


\section{REVISTA DA ABRALIN}

em contextos de divulgação de grande alcance e de elaboração dos processos políticos. Reconhecer alguns dos recursos linguísticos, cognitivos e sociais dos processos políticos se faz importante não apenas para a pesquisa nos estudos da linguagem. Por meio da pesquisa linguística e suas interfaces, reconhecer aquilo de que se constituem os processos políticos se faz importante também aos cidadãos, uma vez que pode auxiliá-los a compreender as forças em andamento na vivência democrática e pode levar a um maior grau de consciência sobre sua conduta inclusive como eleitor, isto é, como aquele que outorga o poder a um mandatário.

Consideramos que a pesquisa linguística tem muito a colaborar nesse sentido, pois dispõe de categorias de análise capazes de embasar técnico-cientificamente, organizar metodologicamente, detalhar ou mesmo contrapor percepções (que muitas vezes os cidadãos sutilmente tenham) sobre as práticas linguísticas dos governantes e sobre as perspectivas estruturantes da realidade veiculadas nos discursos políticos.

\section{Agradecimentos}

Meus agradecimentos às professoras Edwiges Morato, Zilda Aquino e Sandra Cavalcante pela leitura deste trabalho e pelas orientações ao texto. São de minha responsabilidade os desajustes que porventura persistiram.

Agradeço também ao CNPq pelo apoio e fomento que proporcionaram a realização desta pesquisa.

\section{REFERÊNCIAS}

ARONSON, Elise. Cyber-politics: how new media has revolutionized electoral politics in the United States.

Colgate academic Review, Nova Iorque, vol. 9, p. 148-194, 2012.

BENTES; Anna Christina; REZENDE, Renato Cabral. Linguística Textual e Sociolinguística. In: SOUZA, Edson Rosa Francisco de; PENHAVEL, Eduardo; CINTRA, Marcos Rogério. (org.). Linguística Textual - interfaces e

delimitações: homenagem a Ingedore Grunfield Villaça Koch. São Paulo: Cortez, p. 258-301, 2017.

BENTES, Anna Christina; REZENDE, Renato Cabral. O texto como objeto de pesquisa. In: GONÇALVES, Adair. Vieira; GOIS, Marcos Lúcio de Souza. (org.). Ciências da linguagem: o fazer científico. Campinas: Mercado de Letras, p. 137-176, 2014.

BOURDIEU, Pierre. O poder simbólico. 6 ed. Rio de Janeiro: Bertrand Brasil, 2003.

FILLMORE, Charles. Frame semantics and the nature of language. Annals New York Academy of Sciences, Nova Iorque, p. 20-32, 1976. 


\section{REVISTA DA ABRALIN}

GOFFMAN, Erving. Frame analysis: an essay on the organization of experience. Boston: Northeastern University Press, 1974.

HANKS, William. Língua como prática social: das relações entre língua, cultura e sociedade a partir de Bourdieu e Bakhtin. São Paulo: Cortez, 2008.

KOCH, Ingedore Grunfield Villaça. Desvendando os segredos do texto. São Paulo: Cortez, 2002.

KOCH, Ingedore Grunfield Villaça. Introdução à Linguística Textual: trajetória e grandes temas. São Paulo: Martins Fontes, 2004.

LAKOFF, George. Don't think of an elephant: know your values and frame the debate: the essencial guide for progressives. Chelsea Green Publishing Company, 2004.

LAKOFF, George; JOHNSON, Mark. Metaphors We Live By. Chicago: Chicago University Press, 1980.

MACHADO, Debora Franco. A modulação de comportamento nas plataformas de mídias sociais. In: SOUZA, Joyce; AVELINO, Rodolfo; SILVEIRA, Sérgio Amadeu (org.) A sociedade do controle - manipulação e modulação nas redes sociais. Hedra: São Paulo, p. 47-70, 2018.

MARCUSCHI, Luiz Antônio. Anáfora indireta: o barco textual e suas âncoras. In: KOCH, Ingedore Grunfield Villaça; MORATO, Edwiges Maria; BENTES, Anna Christina (org.). Referenciação e Discurso. São Paulo: Contexto, p. 53-101, 2005.

MARCUSCHI, Luiz Antônio. Do código para a cognicão: o processo referencial como atividade criativa. Veredas, Juiz de Fora, v. 6(1), p. 43-62, 2002.

MARCUSCHI, Luiz Antônio. Cognição, linguagem e práticas interacionais. Rio de Janeiro: Lucerna, 2007.

MARTINS, Erik Miletta. Frames neoliberais na retórica neopetencostal: aspectos referenciais e sociocognitivos. 2015. Tese (Doutorado em Linguística) - Instituto de Estudos da Linguagem, Universidade Estadual de Campinas, Campinas, 2007. Disponível em: http://www.repositorio.unicamp.br/bitstream/REPOSIP/270611/1/Martins_ErikFernandoMiletta_D.pdf . Acesso em: 17 mar. 2020.

MIRANDA, Neusa Salim; BERNADO, Flávia Cristina. Frames, discurso e valores. Cadernos de Estudos Linguísticos, Campinas, v. 1, n. 55, p. 81-98, jan./jun., 2013. DOI: https://doi.org/10.20396/cel.v55i1.8636596

MORATO, Edwiges Maria. O interacionismo no campo linguístico. In: MUSSALIM, Fernanda; BENTES, Anna Christina (org.) Introdução à linguística: fundamentos epistemológicos. v. 3 - São Paulo: Cortez, 2004.

MORATO, Edwiges Maria. Das relações entre linguagem, cognição e interação - algumas implicações para o campo da saúde. Linguagem em (Dis)curso, Tubarão, v. 16, n. 3, p. 575-590, set./dez. 2016. DOI: https://doi.org/10.1590/1982-4017-160304-0516d

MORATO, Edwiges Maria. Linguística Textual e Cognição. In: SOUZA, Edson Rosa Francisco de; PENHAVEL, Eduardo; CINTRA, Marcos Rogério (org.). Linguística textual: interfaces e delimitações: homenagem a Ingedore Grunfeld Villaça Koch. São Paulo: Cortez, p. 394-430, 2017.

MORATO, Edwiges Maria et al. O papel dos frames na organização do tópico discursivo e na coesividade comunicacional na interação entre afásicos e não afásicos. Cadernos de Estudos Linguísticos, Campinas, v. 1, n. 59, p. 91-110, jan./abr. 2017. DOI: https://doi.org/10.20396/cel.v59i1.8648347 


\section{REVISTA DA ABRALIN}

MORATO, Edwiges Maria; BENTES, Anna Christina. Frames em jogo na construção discursiva e interativa da referência. Cadernos de Estudos Linguísticos, Campinas, n. 55, v. 1, p. 125-137, jan./jun. 2013. DOI: https://doi.org/10.20396/cel.v55i1.8636599

MORATO, Edwiges Maria; BENTES, Anna Christina. "O mundo tá chato": algumas notas sobre a dimensão sociocognitiva do politicamente correto na linguagem. Revista USP, São Paulo, n. 115, p. 11-28, out./dez. 2017. DOI: https://doi.org/10.11606/issn.2316-9036.v0i115

MOURA, Heronides; GABRIEL, Rosângela. Apresentação. In: MOURA, Heronides; GABRIEL, Rosângela (org.). Cognição e Linguagem. Florianópolis: Insular, p. 9-13, 2012.

REZENDE, Renato Cabral. Expedientes metadiscursivos na articulação e categorização de práticas comunicativas em Relato de um certo oriente, de Milton Hatoum. 2010. Tese (Doutorado em Linguística) - Instituto de Estudos da Linguagem, Universidade Estadual de Campinas, Campinas, 2010. Disponível em: http://repositorio.unicamp.br/bitstream/REPOSIP/269015/1/Rezende_RenatoCabral_D.pdf . Acesso em: 17 mar. 2020.

SALOMÃO, Margarida Martins. Entrevista com Margarida Salomão, J. E. Leite e K. Falcone. Revista Investigações, Recife, v. 23, p. 193-203, 2010. Disponível em: https://periodicos.ufpe.br/revistas/INV/article/view/1407/1071 . Acesso em: 17 mar. 2020.

SIMAN, Josie Helen. Os frames de doença de Alzheimer. 2015. Dissertação (Mestrado em Linguística) - Instituto de Estudos da Linguagem, Universidade Estadual de Campinas, Campinas, 2015. Disponível em: http://repositorio.unicamp.br/bitstream/REPOSIP/270612/1/Siman_JosieHelen_M.pdf . Acesso em 17 mar. 2020 .

TANNEN, Deborah; WALLAT, Cynthia. Interactive frames and knowledge schemas in interaction: examples from a medical examination/interview. Social Psychology Quarterly, 50:2, p. 205-216, 1987.

TOMASELLO, Michael. Origens culturais da aquisição do conhecimento humano. São Paulo: Martins Fontes, 2003.

VAN DIJK, Teun. Discurso e contexto: uma abordagem sociocognitiva. São Paulo: Contexto, 2012. 


\section{REVISTA DA ABRALIN}

PARECER DE LEILANE RAMOS DA SILVA NO ARTIGO "JOÃO DÓRIA: FRAMES EM ESTRATÉGIAS

COMUNICATIVAS DO DISCURSO POLITICO NO FACEBOOK"

DOI 10.25189/rabralin.v19i1.13891

Ao tempo em que estabelece um bom diálogo do referencial teórico com os objetivos escolhidos, o artigo "João Dória: frames em estratégias comunicativas do discurso político no Facebook" destaca uma metodologia interdisciplinar coerente e devidamente apresentada, no que concerne à especificidade das etapas, a par de suas respectivas contribuições. Da mesma sorte, vivifica uma análise híbrida e, a despeito de priorizar um viés quantitativo, lança mão de uma delimitação temporal bem fundamentada para a escolha dos vídeos em estudo, os quais exibem com clareza a linha-raiz de veiculação do discurso político de JD, sediando os frames apontados. Sem dúvida, a análise atende ao que fora previsto na introdução.

Em termos formais, entretanto, quiçá seja importante enxugar o excesso de comentários sobre a importância de cada teórico/estudo citado (a página 6 é exemplo desse peculiar), na medida em que tal postura gera certa circularidade discursiva e, por extensão, cansa o leitor. Igualmente importante observar alguns poucos casos de desajuste na forma de citação de textos/autores.

Pela coerência teórico-metodológica, atualização bibliográfica e contribuição para a área de estudos a que se alinha, sou de parecer favorável à publicação do artigo em avaliação, o qual deve retornar ao(à) autor(à), para leitura de sugestões e eventuais ajustes. 